\title{
HUBUNGAN CEPAT RAMBAT GELOMBANG ULTRASONIK TERHADAP MUTU BETON TANPA AGREGAT KASAR
}

\author{
David Chandra ${ }^{1}$ dan Daniel Christianto ${ }^{2}$ \\ ${ }^{1}$ Program Studi Sarjana Teknik Sipil, Universitas Tarumanagara, Jl. Letjen S. Parman No.1 Jakarta \\ Email: davidc.ts@stu.untar.ac.id \\ ${ }^{2}$ Program Studi Sarjana Teknik Sipil, Universitas Tarumanagara, Jl. Letjen S. Parman No.1 Jakarta \\ Email: daniel@untar.ac.id
}

\begin{abstract}
ABSTRAK
Dalam penelitian ini mempelajari mengenai hubungan cepat rambat gelombang ultrasonik terhadap mutu beton tanpa agregat kasar. Campuran beton yang dibuat tidak menggunakan agregat kasar, hanya semen OPC, pasir silika, air, silica fume, tepung marmer dan superplasticizer. Tujuan tidak digunakannya agregat kasar adalah untuk meningkatkan homogenitas material penyusun beton dan meningkatkan kepadatan kering beton. Maka dari itu dalam material penyusun terdapat tepung marmer sebagai filler dan superplasticizer untuk meningkatkan kepadatan kering, ada juga silica fume juga sebagai filler dan meningkatkan kepadatan kering. Benda uji yang dibuat adalah beton tanpa agregat kasar berbetntuk silinder dengan diameter $10 \mathrm{~cm}$ dan tinggi $20 \mathrm{~cm}$. Nilai cepat rambat didapatkan dengan menggunakan salah satu metode non-destructive test (NDT) yaitu tes Ultrasonic Pulse Velocity (UPV) dengan cara direct/langsung. Nilai kuat tekan didapatkan dengan melakukan uji tekan pada benda uji. Setelah nilai kecepatan dan kuat tekan didapatkan, dibuatlah diagram pencar dan regresinya untuk mendapatkan formula kuat tekan yang baru. Dari penelitian ini dapat disimpulkan bahwa jika nilai cepat rambat semakin tinggi maka nilai mutu beton cenderung tinggi juga, semakin berat massa benda uji maka nilai cepat rambat dan kuat tekan cenderung tinggi juga. Dihasilkan juga formula kuat tekan (f'c) dari hasil regresi yaitu : $f^{\prime} c=-55.578 V^{2}+558.91 V-1322$ dengan satuan standard international.
\end{abstract}

Kata kunci: Beton tanpa Agregat Kasar, Metode Non-destruktif Tes (NDT) , Cepat Rambat Gelombang Ultrasonik, UPV

\section{PENDAHULUAN}

Tidak dapat dipungkiri bahwa negara kita, Indonesia merupakan salah satu negara berkembang dari 195 negara yang terdaftar dalam PBB (Perserikatan Bangsa-Bangsa). Saat ini Indonesia sebagai negara berkembang sedang gencar melakukan pembangunan infrastruktur dengan konsep Indonesia sentris yang bertujuan untuk memudahkan akses masyarakat yang berada di daerah terpencil untuk memenuhi kebutuhannya dan meningkatkan kesejahteraan dalam ekonomi maupun keseragaman dalam kemajuan infrastruktur. Pembangunan infrastruktur ini tentunya tidak lepas dari pemakaian bahan-bahan dari teknologi bahan konstruksi seperti semen, agregat halus, agregat kasar, air, dan bahan tambah atau admixtures lainnya. Bahan-bahan tersebut akan digunakan untuk membuat beton yang merupakan komponen penting membangun suatu bangunan seperti pada struktur bangunan antara lain elemen balok, kolom, fondasi, pelat, perekatan dinding bata, perekatan keramik pada lantai dan lain-lain. Pemilihan beton sebagai bahan konstruksi tentunya memiliki beberapa alasan, seperti beton memiliki umur layan yang panjang dengan biaya perawatan yang murah, mudah dibentuk sesuai dengan bentuk penampangnya dan tentunya dapat didesain sesuai nilai mutu yang diinginkan.

Seiring berjalannya waktu maka kebutuhan penggunaan beton dengan mutu tinggi pun cepat lambat akan digunakan pada konstruksi. Kriteria beton mutu tinggi dimulai dengan nilai kuat tekan lebih besar 41 MPa sedangkan untuk mutu beton biasa nilainnya dibawah $41 \mathrm{MPa}$ hingga $21 \mathrm{MPa}$. Dalam penelitian ini akan dibuatnya benda uji dengan beton tanpa agregat kasar dengan tujuan untuk memperbaiki homogenitas beton dengan tidak menggunakan agregat kasar karena pada dasarnya beton merupakan material yang heterogen yang terdiri dari beberapa unsur penyusun yang berbeda jenis dan ukuran butiran agregat, maka dari itu beton ini dibuat tanpa agregat kasar dengan menggunakan pasir silika dengan lolos saringan no. 30 dan no. 50 dan filler berupa silica fume dan tepung marmer. Tujuan lainnya beton dibuat tanpa agregat kasar adalah untuk meningkatkan kerapatan kepadatan kering. Pengembangan kepadatan yang utama adalah pengurangan kadar air, tetapi kadar air menentukan kemudahan pengerjaan beton. Pada beton normal kepadatan dapat ditingkatkan dengan penambahan partikel pengisi seperti fly 
ash, silica fume dan penggunaan superplastizicer. Penggunaan partikel pengisi seperti silica fume yang optimal \pm 25 $\%$ dari berat semen (Naibaho, 2013).

Dikarenakan beton merupakan salah satu elemen penting dalam suatu struktur maka kekuatannya harus diperiksa secara berkala agar bangunan dapat berfungsi dengan baik. Pemeriksaan ini juga dapat dilakukan dengan berbagai cara, ada dengan cara yang merusak dan tidak merusak beton itu sendiri. dalam penelitian ini, peneliti akan meneliti salah satu metode tidak merusak yaitu ultrasonic pulse velocity test. Metode ultrasonic pulse velocity test sendiri bekerja berdasarkan pengukuran kecepatan gelombang ultrasonik dari saat dikirim hingga diterima kembali oleh alat tersebut. Hasil ultrasonic pulse velocity test dapat digunakan untuk melihat seberapa bagus kualitas dari suatu beton. Semakin cepat gelombang ultrasonik yang diterima kembali setelah dikirim, maka semakin bagus juga kualitas beton tersebut. Maka dari itu tujuan dari penelitian ini adalah untuk mendapatkan korelasi hubungan antara kuat tekan beton tanpa agregat dengan cepat rambat gelombang.

\section{Sejarah tes ultrasonic pulse velocity (UPV)}

Sejak pertengahan tahun 1940-an, ultrasonic pulse velocity test (UPV) sudah mulai diperkenalkan di Amerika dengan mengujinya pada suatu beton. Pada hasil laporannya, ternyata kecepatan sangat bergantung pada nilai modulus elastisitasnya, sehingga sampai saat ini tes UPV hanya dipakai sebatas untuk mengetahui retakan dalam beton dan kualitas suatu beton. Untuk melakukan tes UPV ini digunakan alat ujinya yaitu PUNDIT (Pulse Ultrasonic Non-Destructive Digital Indicating Tester). Hasil dari alat uji PUNDIT berupa kecepetan pulsa yang dilepaskan antar transducer. Salah satu keunggulan pada tes UPV ialah tes ini tidak menyebabkan kerusakan atau perubahan fisik pada benda uji.

Pengukuran cepat rambat gelombang ultrasonik yang merambat pada beton juga dapat untuk mencari tahu beberapa hal (International Atomic Energy Agency, 2002), antara lain:

a. Mengetahui keseragaman dari beton pada suatu struktur maupun antar struktur.

b. Mengukur perubahan yang terjadi pada suatu struktur dari waktu ke waktu.

c. Mengetahui mutu beton dengan korelasi antara kecepatan gelombang ultrasonik dan kuat tekan beton.

d. Mengetahui modulus elastisitas dari beton dan poisson ratio pada beton.

Pada umumnya cara kerja alat PUNDIT (International Atomic Energy Agency, 2002) adalah tranduser memberi getaran gelombang longitudinal melalui cairan pelumas yang berwujud gemuk ataupun sejenis pasta selulose, yang dioleskan pada permukaan beton sebelum tes dimulai. Saat gelombang merambat melalui media yang berbeda, yaitu gemuk dan beton, pada batas gemuk dan beton akan terjadi pantulan gelombang yang merambat dalam bentuk gelombang transversal dan longitudinal. Gelombang transversal merambat tegak lurus lintasan dan gelombang longitudinal merambat sejajar lintasan.Gelombang yang pertama kali yang diterima oleh tranduser adalah gelombang longitudinal. Oleh tranduser, gelombang ini diubah menjadi sinyal gelombang elektronik yang dapat dideteksi oleh tranduser penerima, sehingga waktu tempuh gelombang dapat diukur. Terlihat pada Gambar 1 bagaimana cara kerja alat PUNDIT.

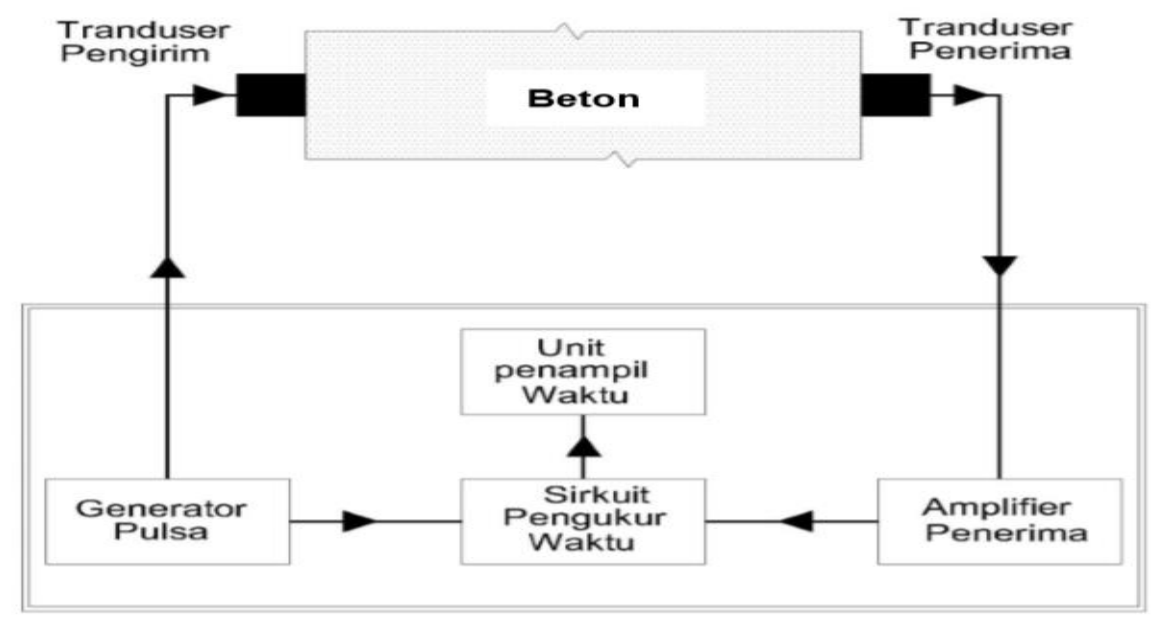

Gambar 1. Proses yang terjadi saat pengambilan data (Badan Standardisasi Nasional, 2012) 


\section{Faktor faktor yang mempengaruhi hasil UPV}

Pada ultrasonic pulse velocity test terdapat beberapa faktor yang dapat mempengaruhi hasilnya (Malhotra, 2004), antara lain:

a. Kondisi material penyusun beton

1) Ukuran, tipe, kandungan dan tingkat gradasi agregat. Kecepatan pulsa pada pasta semen, lebih rendah daripada menggunakan agregat. Beton dengan agregat berbentuk bulat memberikan hasil yang rendah dan beton dengan batu kapur memberikan hasil yang paling tinggi.

2) Tipe semen dan faktor air semen. Variasi pada banyaknya jumlah semen dan tingginya tingkay hidrasi memberikan hasil kecepatan yang berbeda-beda.

3) Bahan tambahan campuran. Bahan tambahan seperti kalsium klorida menghasilkan nilai yang lebih besar.

4) Usia beton.

b. Kondisi lainnya

1) Kontak dengan tranduser. Pengujian dengan metode langsung dan metode tidak langsung memberikan hasil denga perbedaan yang cukup besar.

2) Suhu dan kelembaban beton. Variasi dari temperatur dan kelembaban memberikan hasil yang berbedabeda. Nilai pada beton yang kering lebih tinggi sekitar 5\% daripada beton yang lebih lembab.

3) Lebar, bentuk dan ukuran benda uji yang diukur. Semakin panjang jarak antar tranduser, maka waktu rambatan yang dibutuhkan akan semakin besar.

4) Tegangan pada benda uji dan adanya tulangan. Dengan adanya tulangan, nilai yang terbaca akan lebih tinggi. Karena itu sebisa mungkin tulangan harus dihindarkan.

\section{Prosedur pengambilan data}

Dalam pengambilan data menggunakan alat uji PUNDIT, ada tiga cara untuk melakukannya, yaitu cara langsung (Gambar 2.a), semi-langsung (Gambar 2.b) dan tidak langsung (Gambar 2.c). Pada umumnya saat tes UPV dilakukan di lapangan, cara yang digunakan adalah cara tidak langsung, karena disebabkan oleh beberapa keterbatasan. Sedangkan pada penelitian ini, cara yang digunakan adalah cara langsung karena cara ini menghasilkan hasil yang lebih meyakinkan daripada dua cara lainnya (Bungey, Milard, \& Grantham, 2006).

\section{Interprestasi nilai UPV}

Dari hasil percobaan UPV, akan didapatkan nilai waktu dalam satuan $\mu$ s yang akan digunakan untuk mencari nilai kecepatan menggunakan rumus

$V=\frac{\mathrm{L}}{t)}$

Dengan nilai $\mathrm{V}=$ cepat rambat gelombang $(\mathrm{m} / \mathrm{s}), \mathrm{L}=$ panjang lintasan $(\mathrm{m})$ dan $\mathrm{t}=$ waktu yang didapatkan dari tes $\mathrm{UPV}(\mu \mathrm{s})$

Pada buku (Halliday, Resnick, \& Walker, 2005) memuat sebuah fungsi dasar cepat rambat gelombang longitudinal berdasarkan suatu pegas yaitu:

$V=\sqrt{\frac{\tau}{\varphi}}=\sqrt{\frac{\text { Elastic Property }}{\text { Inertia Property }}}$

Jika gelombang longitudinal merambat pada benda padat, maka fungsi kecepatan akan menjadi:

$$
\begin{aligned}
V & =\sqrt{\frac{E}{\rho}}=\sqrt{\frac{\text { Modulus elastisitas }}{\text { Berat jenis }}} \\
E & =4700 \sqrt{f^{\prime} c}
\end{aligned}
$$

Dalam buku (Neville, 2011) dikatakan bahwa beton harus menggunakan modulus dinamis $\left(\mathrm{E}_{\mathrm{d}}\right)$ sehingga rumus kecepatan rambat menjadi:

$V^{2}=\frac{\mathrm{Ed}(1-\mu)}{\rho(1+\mu)(1-2 \mu)}$

Berikut adalah hubungan modulus statis dan dinamis sehingga nantinya bisa didapatkan nilai kuat tekan (f'c) (Lydon \& Balendran, 1986):

$E=0.83 E d$ 
Dengan keterangan semua persamaan diatas adalah $\mathrm{V}=$ cepat rambat gelombang $(\mathrm{m} / \mathrm{s})$, $\mathrm{E}=$ Modulus elastisitas statis $\left(\mathrm{N} / \mathrm{mm}^{2}\right), \mathrm{Ed}=$ Modulus elastisitas dinamis $\left(\mathrm{N} / \mathrm{mm}^{2}\right), \rho=$ Berat jenis $\left(\mathrm{Kg} / \mathrm{m}^{3}\right)$

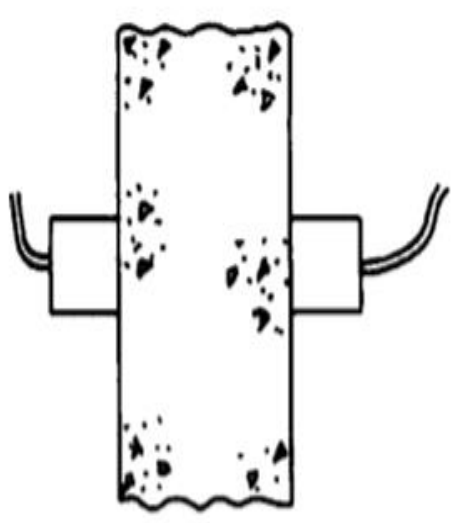

(a)

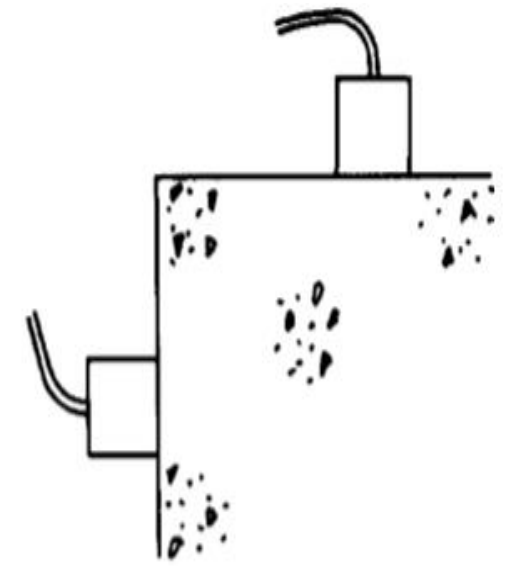

(b)

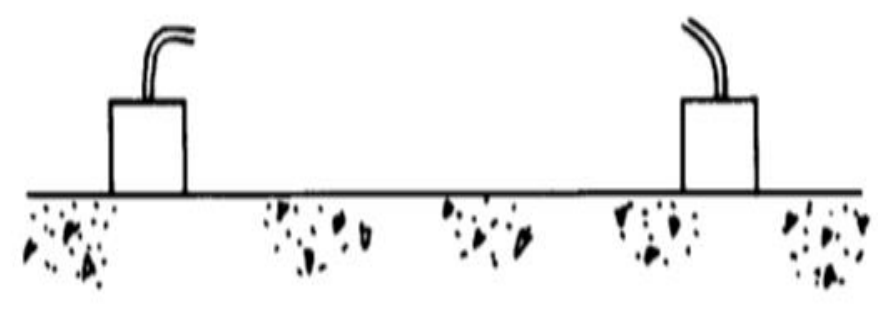

(c)

Gambar 2. Metode pengambilan data dengan PUNDIT (Bungey, Milard, \& Grantham, 2006)

\section{PROSEDUR PENELITIAN}

Metode yang digunakan adalah metode eksperimental. Yang dimaksud dengan metode eksperimental adalah dimana peneliti mencoba membuat benda uji yang akan dites untuk mengetahui nilai-nilai yang dibutuhkan seperti nilai mutu beton dan cepat rambat gelombang pada benda uji. Ukuran benda uji yang dibuat adalah silinder berukuran 10 $\mathrm{cm}$ × $20 \mathrm{~cm}$ Untuk urutan pengerjaan pada penelitian dapat dilihat pada Gambar 3. Adapun bahan-bahan yang digunakan adalah semen OPC, pasir silika dengan ukuran lolos saringan no. 30 dan 50, tepung marmer yang telah lolos saringan no. 200, silica fume, superplasticizer dan air yang merupakan air keran dari Laboratorium Teknologi Bahan Konstruksi Jurusan Teknik Sipil Universitas Tarumanagara Jakarta yang dicampur dengan es batu. Dari desain campuran sesuai dengan Tabel 1 ditargetkan benda uji memiliki kuat tekan antara $50 \mathrm{MPa}$ hingga $100 \mathrm{MPa}$. Perawatan benda uji dilakukan dengan perendaman di dalam kolam selama 58 hari dan steam selama 8 jam. Setelah perawatan selesai, maka dilakukanlah pengujian ultrasonic pulse velocity yang dilanjutkan dengan tes kuat tekan.

Tabel 1. Desain campuran semua benda uji dengan persentase dibandingkan dengan massa semen

\begin{tabular}{ccccc}
\hline Desain Campuran & I & II & III & IV \\
\hline Faktor air semen & $19 \%$ & $18 \%$ & & $20 \%$ \\
\hline Pasir & \multicolumn{3}{c}{$110 \%$} \\
\hline Tepung marmer & \multicolumn{3}{c}{$10 \%$} \\
\hline Silica fume & \multicolumn{3}{c}{$20 \%$} \\
\hline Superplasticizer & $2.50 \%$ & $3 \%$ & $2 \%$ \\
\hline
\end{tabular}




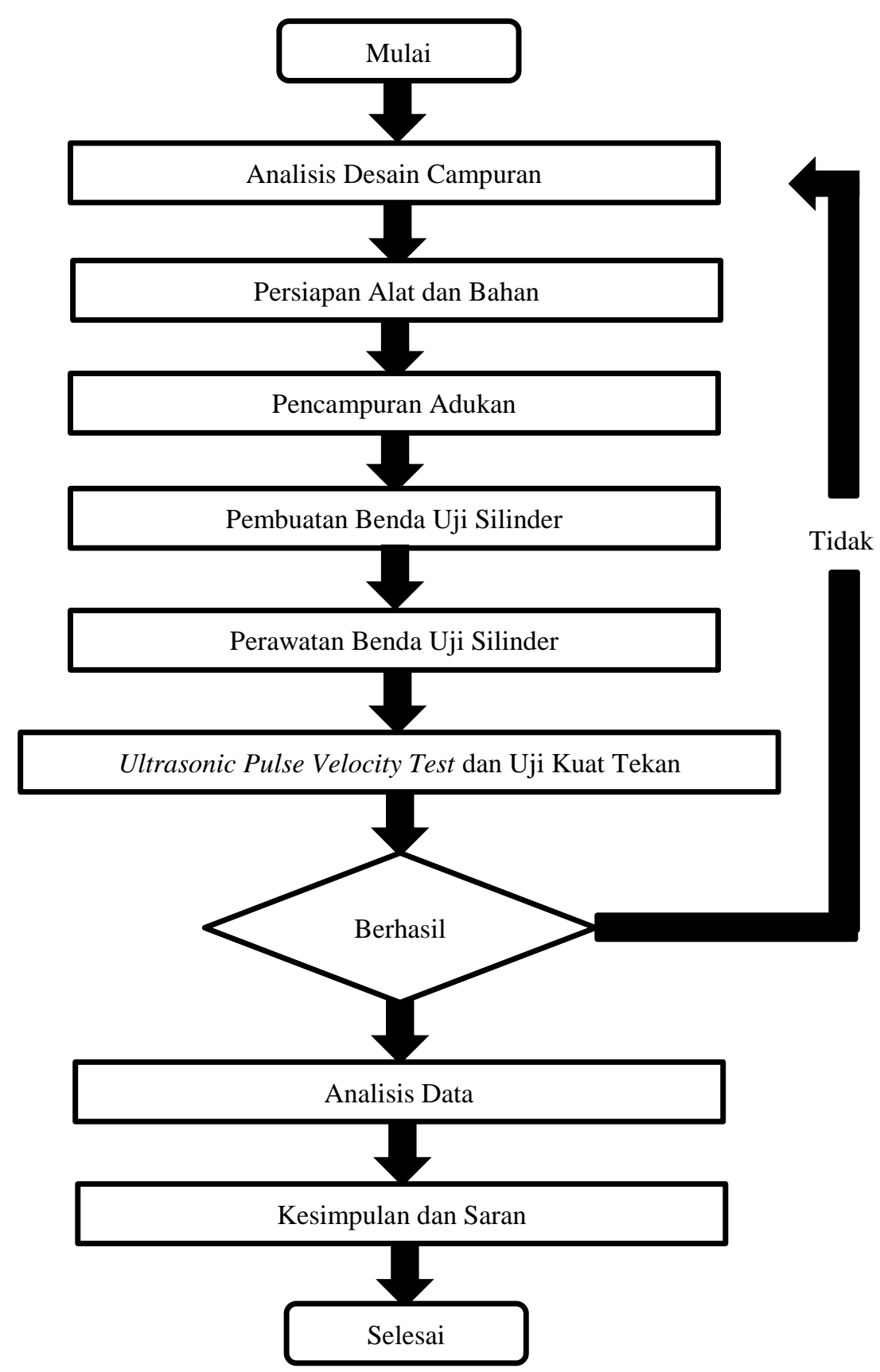

Gambar 3. Diagram alir penelitian

\section{HASIL PENELITIAN DAN PEMBAHASAN}

Sebelum dilakukannya pengujian tes ultrasonic pulse veocity dan kuat tekan, terlebih dahulu dikumpulkan data-data dari benda uji seperti volume benda uji dan massa benda uji yang nantinya akan digunakan untuk mencari nilai berat jenis benda uji. Terlihat pada Tabel 2 merupakan data massa, volume dan berat jenis benda uji.

Tabel 2. Volume, massa, dan volume seluruh benda uji

\begin{tabular}{cccc}
\hline Benda Uji & $\begin{array}{c}\text { Volume Benda Uji } \\
\left(\mathrm{m}^{3}\right)\end{array}$ & $\begin{array}{c}\text { Massa Benda } \\
\text { Uji }(\text { gram })\end{array}$ & $\begin{array}{c}\text { Berat Jenis } \\
\left(\mathrm{Kg} / \mathrm{m}^{3}\right)\end{array}$ \\
\hline 1 & 0.00157 & 3649.5 & 2324.522293 \\
\hline 2 & 0.00157 & 3404.5 & 2168.471338 \\
\hline 3 & 0.00157 & 3606 & 2296.815287 \\
\hline
\end{tabular}




\begin{tabular}{cccc}
\hline Benda Uji & $\begin{array}{c}\text { Volume Benda Uji } \\
\left(\mathrm{m}^{3}\right)\end{array}$ & $\begin{array}{c}\text { Massa Benda } \\
\text { Uji }(\text { gram })\end{array}$ & $\begin{array}{c}\text { Berat Jenis } \\
\left(\mathrm{Kg} / \mathrm{m}^{3}\right)\end{array}$ \\
\hline 4 & 0.00157 & 3596.5 & 2290.764331 \\
\hline 5 & 0.00157 & 3525.5 & 2245.541401 \\
\hline 6 & 0.00157 & 3399 & 2164.968153 \\
\hline 7 & 0.00157 & 3456.5 & 2201.592357 \\
\hline 8 & 0.00157 & 3529.5 & 2248.089172 \\
\hline 9 & 0.00157 & 3729 & 2375.159236 \\
\hline 10 & 0.00157 & 3435.5 & 2188.216561 \\
\hline 11 & 0.00157 & 3603.5 & 2295.22293 \\
\hline 12 & 0.00157 & 3582 & 2281.528662 \\
\hline 13 & 0.00157 & 3481.5 & 2217.515924 \\
\hline 14 & 0.00157 & 3538 & 2253.503185 \\
\hline 15 & 0.00157 & 3492 & 2224.203822 \\
\hline 16 & 0.00157 & 3436 & 2188.535032 \\
\hline 17 & 0.00157 & 3556.5 & 2265.286624 \\
\hline 18 & 0.00157 & 3430.5 & 2185.031847 \\
\hline 19 & 0.00157 & 3500 & 2229.299363 \\
\hline 20 & 0.00157 & 3582 & 2281.528662 \\
\hline 21 & 0.00157 & 3639 & 2317.834395 \\
\hline 22 & 0.00157 & 3360 & 2140.127389 \\
\hline 23 & 0.00157 & 3413 & 2173.88535 \\
\hline
\end{tabular}

Setelah dikumpulkan data berat jenis, maka benda uji siap untuk dites UPV dan uji tekam, berikut hasil pengujian dapat dilihat pada Tabel 3 beserta data pencarnya pada Gambar 4.

Tabel 3. Data hasil tes UPV dan tes kuat tekan

\begin{tabular}{|c|c|c|}
\hline $\begin{array}{l}\text { Benda } \\
\text { Uji }\end{array}$ & $\begin{array}{l}\text { Cepat Rambat Gelombang } \\
(\mathrm{Km} / \mathrm{s})\end{array}$ & $\begin{array}{c}\text { Kuat Tekan } \\
\left(\mathrm{N} / \mathrm{mm}^{2}\right)\end{array}$ \\
\hline 1 & 4.807692308 & 78.55 \\
\hline 2 & 4.454342984 & 62.37 \\
\hline 3 & 4.587155963 & 65.73 \\
\hline 4 & 4.357298475 & 59.44 \\
\hline 5 & 4.454342984 & 58.51 \\
\hline 6 & 4.405286344 & 55.99 \\
\hline 7 & 4.64037123 & 74.4 \\
\hline 8 & 4.504504505 & 68.91 \\
\hline 9 & 4.750593824 & 82.32 \\
\hline 10 & 4.454342984 & 56.49 \\
\hline 11 & 4.926108374 & 78.2 \\
\hline 12 & 4.926108374 & 93.38 \\
\hline 13 & 4.555808656 & 72.5 \\
\hline 14 & 4.64037123 & 77.38 \\
\hline 15 & 4.555808656 & 74.27 \\
\hline 16 & 4.357298475 & 65.79 \\
\hline 17 & 4.866180049 & 72.13 \\
\hline 18 & 4.357298475 & 50.5 \\
\hline 19 & 4.587155963 & 58.7 \\
\hline 20 & 4.555808656 & 77.56 \\
\hline 21 & 4.64037123 & 82.23 \\
\hline 22 & 4.405286344 & 71.23 \\
\hline 23 & 4.504504505 & 79.54 \\
\hline
\end{tabular}




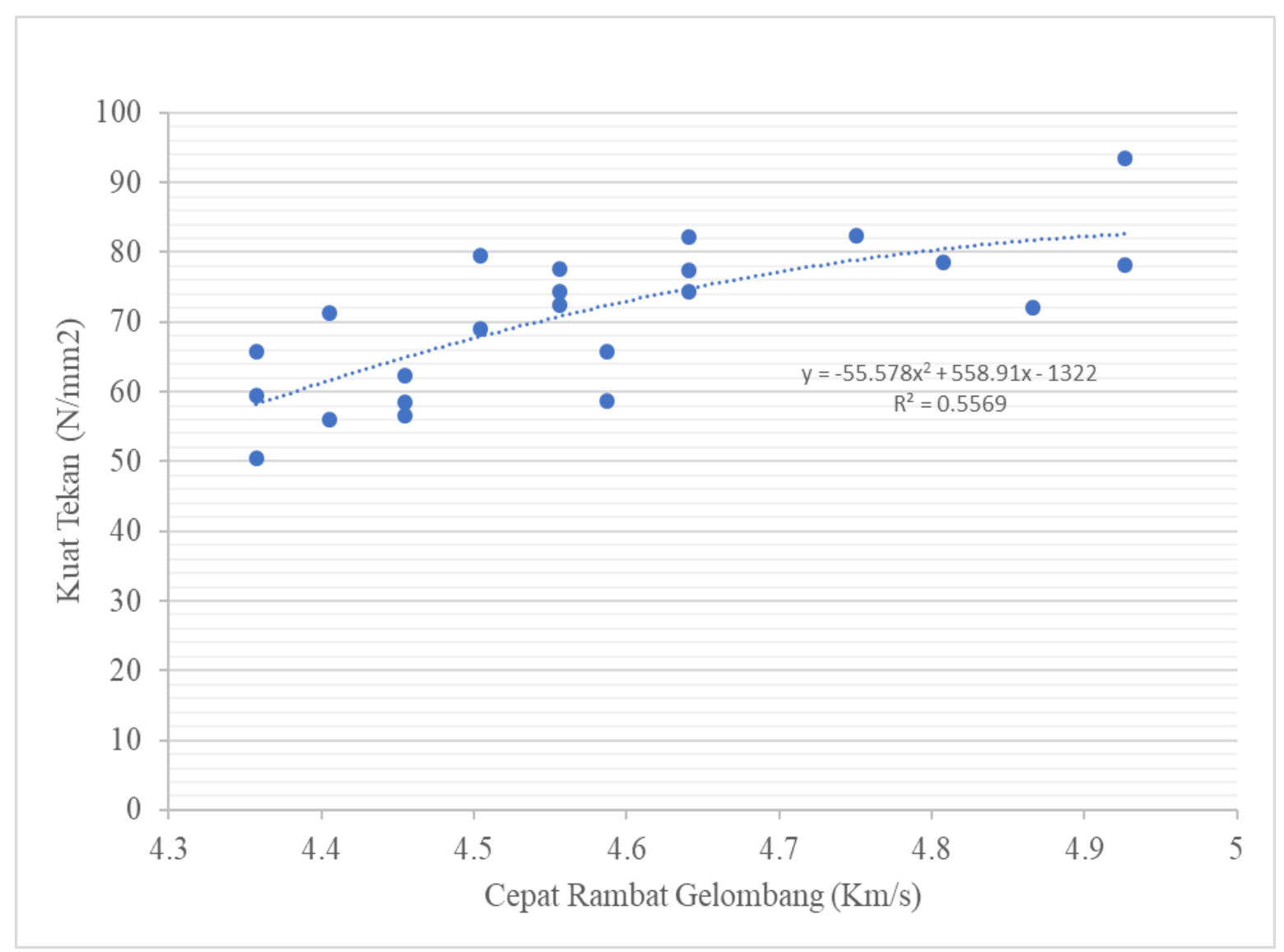

Gambar 4. Grafik korelasi cepat rambat gelombang ultrasonik dan kuat tekan

Dalam penelitian ini nilai cepat rambat gelombang dikaitkan dengan nilai modulus elastisitas dinamis. Dengan kaitan ini, penulis mencoba mencari nilai kuat tekan beton dengan hubungan modulus elastisitas beton dengan kuat tekan. Untuk mencari nilai kuat tekan, diperlukannya nilai modulus elastisitas dinamis (Ed) dan statis (E) agar nantinya dapat diubah menjadi nilai kuat tekan, persamaan ini terdapat di dalam Persamaan 5 dan 6 . Pada Tabel 4 merupakan hasil perhitungan persamaan dan kuat tekan aktual yang didapatkan dari hasil tes kuat tekan

Tabel 4. Nilai kuat tekan berdasarkan kuat tekan teori dan perbandingannya dengan hasil praktikum

\begin{tabular}{cccccc}
\hline $\begin{array}{c}\text { Benda } \\
\text { Uji }\end{array}$ & $\begin{array}{c}\text { Cepat Rambat } \\
\text { Gelombang } \\
(\mathrm{Km} / \mathrm{s})\end{array}$ & $\begin{array}{c}\text { Berat Jenis } \\
\left(\mathrm{Kg} / \mathrm{m}^{3}\right)\end{array}$ & $\begin{array}{c}\text { Modulus } \\
\text { Elastisitas } \\
\text { Dinamis } \\
\left(\mathrm{N} / \mathrm{mm}^{2}\right)\end{array}$ & $\begin{array}{c}\text { Kuat } \\
\text { tekan } \\
\text { teori } \\
\left(\mathrm{N} / \mathrm{mm}^{2}\right)\end{array}$ & $\begin{array}{c}\text { Kuat } \\
\text { Tekan } \\
\text { Aktual } \\
\left(\mathrm{N} / \mathrm{mm}^{2}\right)\end{array}$ \\
\hline 1 & 4.807692308 & 2324.522 & 50884.323 & 80.75 & 78.55 \\
\hline 2 & 4.454342984 & 2168.471 & 40747.217 & 51.78 & 62.37 \\
\hline 3 & 4.587155963 & 2296.815 & 45770.962 & 65.33 & 65.73 \\
\hline 4 & 4.357298475 & 2290.764 & 41190.019 & 52.91 & 59.44 \\
\hline 5 & 4.454342984 & 2245.541 & 42195.422 & 55.53 & 58.51 \\
\hline 6 & 4.405286344 & 2164.968 & 39790.258 & 49.38 & 55.99 \\
\hline 7 & 4.64037123 & 2201.592 & 44897.206 & 62.86 & 74.4 \\
\hline 8 & 4.504504505 & 2248.089 & 43200.079 & 58.20 & 68.91 \\
\hline 9 & 4.750593824 & 2375.159 & 50765.128 & 80.37 & 82.32 \\
\hline 10 & 4.454342984 & 2188.217 & 41118.244 & 52.73 & 56.49 \\
\hline 11 & 4.926108374 & 2295.223 & 52748.456 & 86.77 & 78.2 \\
\hline 12 & 4.926108374 & 2281.529 & 52433.737 & 85.74 & 93.38 \\
\hline 13 & 4.555808656 & 2217.516 & 43588.774 & 59.25 & 72.5 \\
\hline 14 & 4.64037123 & 2253.503 & 45955.827 & 65.86 & 77.38 \\
\hline 15 & 4.555808656 & 2224.204 & 43720.235 & 59.61 & 74.27 \\
\hline 16 & 4.357298475 & 2188.535 & 39351.843 & 48.29 & 65.79 \\
\hline
\end{tabular}




\begin{tabular}{cccccc}
\hline $\begin{array}{c}\text { Benda } \\
\text { Uji }\end{array}$ & $\begin{array}{c}\text { Cepat Rambat } \\
\text { Gelombang } \\
(\mathrm{Km} / \mathrm{s})\end{array}$ & $\begin{array}{c}\text { Berat Jenis } \\
\left(\mathrm{Kg} / \mathrm{m}^{3}\right)\end{array}$ & $\begin{array}{c}\text { Modulus } \\
\text { Elastisitas } \\
\text { Dinamis } \\
\left(\mathrm{N} / \mathrm{mm}^{2}\right)\end{array}$ & $\begin{array}{c}\text { Kuat } \\
\text { tekan } \\
\text { teori } \\
\left(\mathrm{N} / \mathrm{mm}^{2}\right)\end{array}$ & $\begin{array}{c}\text { Kuat } \\
\text { Tekan } \\
\text { Aktual } \\
\left(\mathrm{N} / \mathrm{mm}^{2}\right)\end{array}$ \\
\hline 17 & 4.866180049 & 2265.287 & 50801.491 & 80.48 & 72.13 \\
\hline 18 & 4.357298475 & 2185.032 & 39288.853 & 48.14 & 50.5 \\
\hline 19 & 4.587155963 & 2229.299 & 44425.504 & 61.55 & 58.7 \\
\hline 20 & 4.555808656 & 2281.529 & 44847.045 & 62.72 & 77.56 \\
\hline 21 & 4.64037123 & 2317.834 & 47267.737 & 69.68 & 82.23 \\
\hline 22 & 4.405286344 & 2140.127 & 39333.706 & 48.25 & 71.23 \\
\hline 23 & 4.504504505 & 2173.885 & 41774.152 & 54.42 & 79.54 \\
\hline
\end{tabular}

Pada Tabel 5 dan Gambar 5 terlihat jika kuat tekan diurutkan dari kuat tekan terkecil hingga paling tinggi, nilai ratarata cepat rambat gelombangnya semakin tinggi juga. Hasil ini membuktikan bahwa semakin tinggi nilai kuat tekan maka semakin cepat juga nilai cepat rambat gelombangnya.

Tabel 5. Nilai kuat tekan berdasarkan variannya beserta cepat rambat gelombang

\begin{tabular}{|c|c|c|c|c|c|c|}
\hline $\begin{array}{c}\text { Cepat } \\
\text { Rambat } \\
\text { Gelombang } \\
(\mathrm{Km} / \mathrm{s})\end{array}$ & $\begin{array}{c}\text { Massa } \\
\text { Benda } \\
\text { Uji } \\
\text { (gram) }\end{array}$ & $\begin{array}{c}\text { Kuat } \\
\text { Tekan } \\
\text { Aktual } \\
\left(\mathrm{N} / \mathrm{mm}^{2}\right)\end{array}$ & $\begin{array}{c}\text { Rata-Rata } \\
\text { Kuat } \\
\text { Tekan } \\
\text { Aktual } \\
\left(\mathrm{N} / \mathrm{mm}^{2}\right)\end{array}$ & $\begin{array}{l}\text { Rata-Rata } \\
\text { Massa } \\
\text { Benda Uji } \\
\text { (gram) }\end{array}$ & $\begin{array}{c}\text { Rata-Rata } \\
\text { Cepat Rambat } \\
\text { Gelombang } \\
(\mathrm{Km} / \mathrm{s})\end{array}$ & $\begin{array}{c}\text { Kualitas } \\
\text { Beton }\end{array}$ \\
\hline 4.3572985 & 3430.5 & 50.5 & \multirow{6}{*}{56.6} & \multirow{6}{*}{3481.2} & \multirow{6}{*}{4.4} & \multirow{6}{*}{ Bagus } \\
\hline 4.4052863 & 3399 & 55.99 & & & & \\
\hline 4.454343 & 3435.5 & 56.49 & & & & \\
\hline 4.454343 & 3525.5 & 58.51 & & & & \\
\hline 4.587156 & 3500 & 58.7 & & & & \\
\hline 4.3572985 & 3596.5 & 59.44 & & & & \\
\hline 4.454343 & 3404.5 & 62.37 & \multirow{4}{*}{65.7} & \multirow{4}{*}{3494.0} & \multirow{4}{*}{4.5} & \multirow{4}{*}{ Bagus } \\
\hline 4.587156 & 3606 & 65.73 & & & & \\
\hline 4.3572985 & 3436 & 65.79 & & & & \\
\hline 4.5045045 & 3529.5 & 68.91 & & & & \\
\hline 4.4052863 & 3360 & 71.23 & \multirow{10}{*}{75.6} & \multirow{10}{*}{3513.3} & \multirow{10}{*}{4.6} & \multirow{10}{*}{ Sangat Bagus } \\
\hline 4.86618 & 3556.5 & 72.13 & & & & \\
\hline 4.5558087 & 3481.5 & 72.5 & & & & \\
\hline 4.5558087 & 3492 & 74.27 & & & & \\
\hline 4.6403712 & 3456.5 & 74.4 & & & & \\
\hline 4.6403712 & 3538 & 77.38 & & & & \\
\hline 4.5558087 & 3582 & 77.56 & & & & \\
\hline 4.9261084 & 3603.5 & 78.2 & & & & \\
\hline 4.8076923 & 3649.5 & 78.55 & & & & \\
\hline 4.5045045 & 3413 & 79.54 & & & & \\
\hline 4.6403712 & 3639 & 82.23 & \multirow{2}{*}{82.3} & \multirow{2}{*}{3684.0} & \multirow{2}{*}{4.7} & \multirow{2}{*}{ Sangat Bagus } \\
\hline 4.7505938 & 3729 & 82.32 & & & & \\
\hline 4.9261084 & 3582 & 93.38 & 93.4 & 3582.0 & 4.9 & Sangat Bagus \\
\hline
\end{tabular}




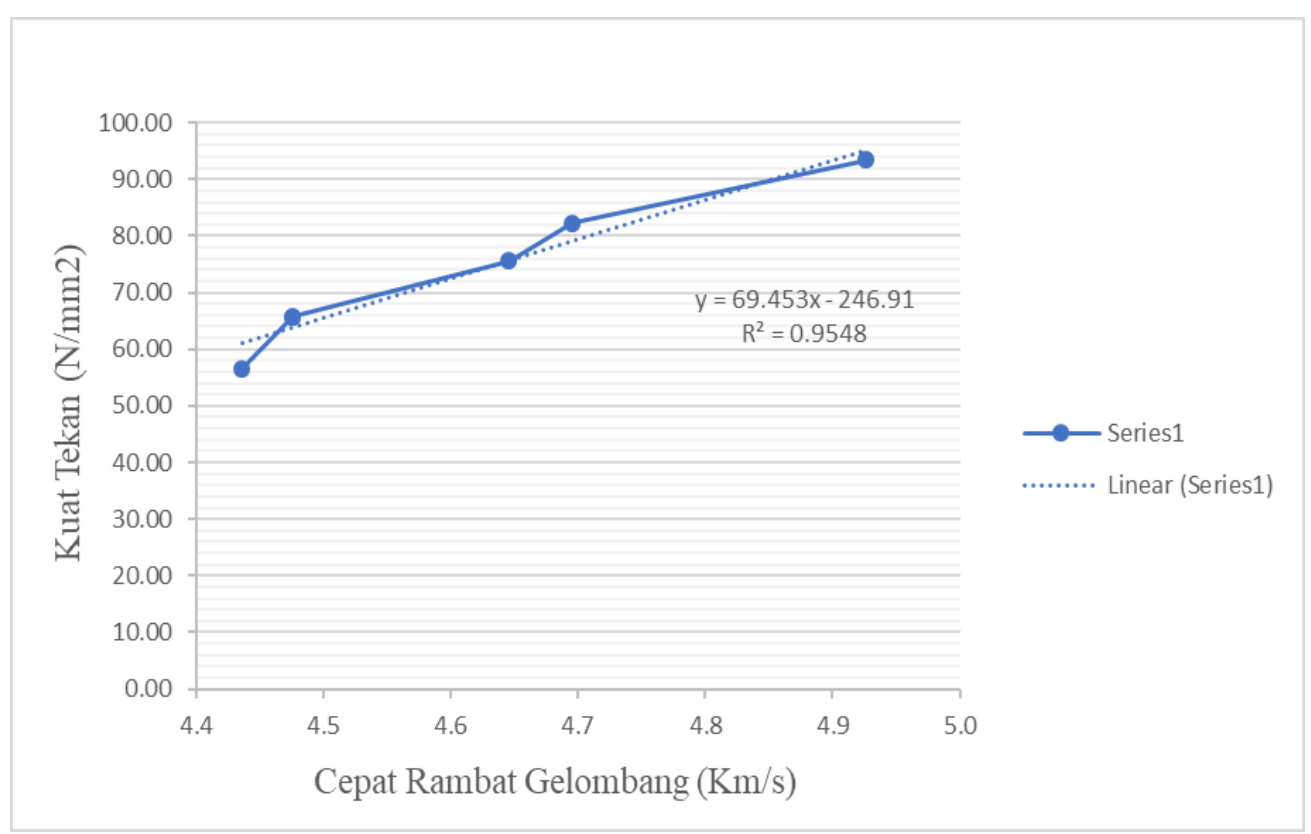

Gambar 5. Grafik rata-rata cepat rambat gelombang ultrasonik dan mutu beton

Dari hasil regresi maka didapatkanlah formula berupa $f^{\prime} c=-55.578 V^{2}+558.91 V-1322$. Dari formula yang ada maka diperhitungkanlah nilai f'c regresi dengan mengunakan formula yang didapatkan. Pada Tabel 6 merupakan hasil perhitungan dari formula regresi beserta selisih perbedaannya dengan nilai kuat tekan aktual

Tabel 6. Selisih nilai kuat tekan regresi dan aktual

\begin{tabular}{ccccc}
\hline $\begin{array}{c}\text { Benda } \\
\text { Uji }\end{array}$ & $\begin{array}{c}\text { Cepat Rambat } \\
\text { Gelombang } \\
(\mathrm{Km} / \mathrm{s})\end{array}$ & $\begin{array}{c}\text { Kuat tekan } \\
\text { Regresi } \\
\left(\mathrm{N} / \mathrm{mm}^{2}\right)\end{array}$ & $\begin{array}{c}\text { Kuat Tekan } \\
\text { Aktual } \\
\left(\mathrm{N} / \mathrm{mm}^{2}\right)\end{array}$ & $\begin{array}{c}\text { Selisih } \\
(\%)\end{array}$ \\
\hline 1 & 4.8076923 & 80.44 & 78.55 & 2.41 \\
\hline 2 & 4.454343 & 64.84 & 62.37 & 3.97 \\
\hline 3 & 4.587156 & 72.34 & 65.73 & 10.05 \\
\hline 4 & 4.3572985 & 58.13 & 59.44 & 2.20 \\
\hline 5 & 4.454343 & 64.84 & 58.51 & 10.83 \\
\hline 6 & 4.4052863 & 61.58 & 55.99 & 9.99 \\
\hline 7 & 4.6403712 & 74.79 & 74.4 & 0.52 \\
\hline 8 & 4.5045045 & 67.90 & 68.91 & 1.46 \\
\hline 9 & 4.7505938 & 78.86 & 82.32 & 4.20 \\
\hline 10 & 4.454343 & 64.84 & 56.49 & 14.79 \\
\hline 11 & 4.9261084 & 82.57 & 78.2 & 5.58 \\
\hline 12 & 4.9261084 & 82.57 & 93.38 & 11.58 \\
\hline 13 & 4.5558087 & 70.74 & 72.5 & 2.42 \\
\hline 14 & 4.6403712 & 74.79 & 77.38 & 3.35 \\
\hline 15 & 4.5558087 & 70.74 & 74.27 & 4.75 \\
\hline 16 & 4.3572985 & 58.13 & 65.79 & 11.64 \\
\hline 17 & 4.86618 & 81.69 & 72.13 & 13.25 \\
\hline 18 & 4.3572985 & 58.13 & 50.5 & 15.11 \\
\hline 19 & 4.587156 & 72.34 & 58.7 & 23.23 \\
\hline 20 & 4.5558087 & 70.74 & 77.56 & 8.79 \\
\hline 21 & 4.6403712 & 74.79 & 82.23 & 9.05 \\
\hline 22 & 4.4052863 & 61.58 & 71.23 & 13.55 \\
\hline 23 & 4.5045045 & 67.90 & 79.54 & 14.63 \\
\hline & & & &
\end{tabular}




\section{KESIMPULAN}

Berdasarkan dari hasil pengujian di laboratorium dan analisis data, maka didapatkan kesimpulan antara lain:

a. Semakin tinggi kuat tekan maka nilai cepat rambat gelombang cenderung semakin tinggi, terlihat pada Tabel 5.

b. Semakin berat massa benda uji, nilai cepat rambat gelombang dan kuat tekan cenderung semakin tinggi.

c. Dari hasil korelasi antara cepat rambat gelombang dengan mutu beton, didapatkanlah formula kuat tekan dengan nilai $\mathrm{R}^{2}$ sebesar 0.5569

$$
f^{\prime} c=-55.578 V^{2}+558.91 V-1322
$$

Formula ini hanya bisa digunakan pada beton tanpa agregat dengan bahan yang kurang lebih sama.

\section{DAFTAR PUSTAKA}

Badan Standardisasi Nasional. (2012). Metode Uji Kecepatan Rambat Gelombang Melalui Beton (ASTM C 597 02, IDT). Jakarta: Badan Standardisasi Nasional.

Bungey, J. H., Milard, S. G., \& Grantham, M. G. (2006). Testing of Concrete in Structures, 4th Edition. United States of America: Taylor \& Francis.

Halliday, D., Resnick, R., \& Walker, J. (2005). Fundamentals of Physics. United States of America: John Wiley \& Sons Inc.

International Atomic Energy Agency. (2002). Guidebook on Non-Destructive Testing of Concrete Structures. Austria: International Atomic Energy Agency.

Lydon, \& Balendran. (1986). Some Observations on Elastic Properties of Plain Concrete. Cement and Concrete Research.

Malhotra, V. M. (2004). Handbook on Nondestructive Testing of Concrete, Second Edition. CRC Press.

Naibaho, P. R. (2013). "Perilaku Hubungan Balok-Kolom Eksterior Beton Normal, Mutu Tinggi, \& Bubuk Reaktif Dengan Beban Lateral Siklik (104S)". Konferensi Nasional Teknik Sipil 7 (KONTEKS 7) Universitas Sebelas Maret (UNS). Surakarta, 24-26 Oktober 2013, 115-122

Neville, A. M. (2011). Properties of Concrete, 5th Edition. Malaysia: Pearson. 